\title{
Free Endotoxin and \\ Non-toxic Material from Gram-negative Bacteria: Electron Microscopy of Fractions from Escherichia coli
}

\author{
By D. G. MARSH* AND P. D. WALKER \\ Departments of Bacteriology and Anaerobic Bacteriology, \\ Wellcome Research Laboratories, Beckenham, Kent
}

(Accepted for publication 30 November 1967)

SUMMARY

Toxic and non-toxic fractions, isolated from culture supernatant fluids or from organisms of Escherichia coli $\mathrm{O}_{7} 8 \mathrm{~K} 80$, were examined with the electron microscope after negative staining with phosphotungstate. Preparations of endotoxin from the supernatant fluids ('free endotoxin') contained large numbers of rod-like particles, considered to be the native undegraded endotoxic lipopolysaccharide-protein complex. Phenol-water extraction of either free endotoxin particles or whole organisms caused aggregation of the complex, leading to chain-like structures. Both 'rods' and 'chains' were observed in an endotoxin preparation extracted from organisms by aqueous ether. A non-toxic predominantly polysaccharidic preparation from $E$. coli was not visible after negative staining; but this fraction, and to a lesser extent the toxic fractions derived from culture supernatant fluids, were found to contain well-defined fragments believed to be derived from the bacterial cell wall.

\section{INTRODUCTION}

An appreciable quantity of 'free endotoxin' is secreted into the culture fluid of a Gram-negative bacterium grown to a high population density under intensive growth conditions (Crutchley, Marsh \& Cameron, I967a). The isolation and properties of toxic and non-toxic lipopolysaccharide-protein complexes from the culture supernatant of a strain of Escherichia coli, $\mathrm{O}_{7} 8 \mathrm{~K} 80$, have been described in detail (Marsh \& Crutchley, I966; Marsh \& Crutchley, I967; Crutchley, Marsh \& Cameron, I968b).

Purified free endotoxin (Fraction D2.S I for detailed nomenclature of fractions see Marsh \& Crutchley, 1967) was found to be indistinguishable biologically from conventional cell-wall endotoxin obtained by extracting Gram-negative bacteria with aqueous phenol according to the procedure of Westphal, Lüderitz, Eichenberger \& Keiderling (1952) or with aqueous ether (Ribi, Haskins, Landy \& Milner, 196I). Fraction D 2.S I had a much higher peptide content than purified cell-wall endotoxin preparations which had been deproteinated with phenol-water at $65^{\circ}$ (Westphal et al. 1952; Ribi et al. 1964). The ratios of lipid to polysaccharide for all preparations of endotoxin from Escherichia coli were similar.

The highly purified free non-toxic fraction ( $D_{I}$. $_{I}$ ) had similar properties to the

* Present address: Gates and Crellin Laboratories of Chemistry, California Institute of Technology, Pasadena, California, U.S.A. 
so-called 'native hapten', a protoplasmic component of Escherichia coli extracted by Anacker et al. (1964). These workers originally proposed that this substance was a structural element of endotoxin; but later work by Rudbach et al. (1967) clearly invalidated this hypothesis, in full agreement with the findings of Marsh \& Crutchley (1967). Rudbach et al. (1967) redesignated this non-toxic product 'native protoplasmic polysaccharide' (NPP).

The present electron microscopic examination of fractions from Escherichia coli was undertaken with the aim of comparing the structures of 'free' and 'cell-wall' endotoxins, and also to investigate whether any structural relationship between non-toxic and toxic fractions could be observed. It was not possible to make this latter comparison because of failure to obtain pictures of the non-toxic fraction. However, electron microscopy revealed the presence of large fragments, believed to be derived from the cell wall, in many of the fractions examined.

\section{METHODS}

Lipopolysaccharide preparations. Escherichia coli $\mathrm{O} 78 \mathrm{~K} 80$ was grown in a vigorously aerated casein sucrose medium and the resulting supernatant solution fractionated to yield non-toxic and toxic lipopolysaccharide-protein complexes, D I . S I and D 2 . S I respectively (Marsh \& Crutchley, 1967). Loosely bound protein was removed from both fractions by a modification of the procedure of Westphal et al. (1952).

A $90 \%$ phenol in water mixture $(5 \mathrm{ml}$.) was added to a solution of fraction D 2 . S I or D I.S I ( $20 \mathrm{mg}$.) in water $(5 \mathrm{ml}$.). The resulting mixture was shaken for $30 \mathrm{~min}$. in a water bath at $65^{-}-68^{\circ}$ and centrifuged at $4^{\circ}$. The aqueous layer was removed, dialysed against distilled water and freeze-dried (yields: $15-17 \mathrm{mg}$.).

Purified cell-wall endotoxic fractions $\mathrm{P}_{\mathrm{I}}$ and $\mathrm{E}$, from aqueous phenol and aqueous ether extracts of bacteria harvested from the aforementioned culture of Escherichia coli, were prepared as described by Marsh \& Crutchley (I967), by using modifications of earlier methods of Westphal et al. (1952) and Ribi et al. (I96I).

Electron microscopy. Lipopolysaccharide preparations were examined by negative staining with phosphotungstate. A I \% (w/v) solution of phosphotungstic acid, adjusted to $\mathrm{pH} 5.3$ with $2 \mathrm{~N}-\mathrm{NaOH}$, was mixed with an equal volume of a $0.1 \%$ aqueous solution of the lipopolysaccharide under investigation. The mixture was applied as a drop to a carbon-coated copper microscope grid and excess liquid carefully removed by blotting with filter paper. The sample was examined under a Phillips Model EM 200 electron microscope at a magnification of 71,000 .

Preliminary experiments, with uranyl acetate as an alternative negative staining agent, showed that structural details on the complex molecules could be distinguished with a similar degree of resolution as with the phosphotungstate stain.

\section{RESULTS AND DISCUSSION}

\section{Endotoxins}

Plate I, fig. I, shows an electron micrograph of the crude material precipitated from the culture supernatant fluid by adding ammonium sulphate to saturation point. The rod-like particles visible in this picture were prominent in the purified preparation of free endotoxin derived from the crude precipitated material (Fraction 
D 2.S I ; P1. I, fig. 2); these 'rods' are considered to be the toxic lipopolysaccharideprotein complex. Measurement of six well-defined rods, lying with their axes parallel to the plane of the grid, showed their average dimensions to be $295 \pm 15 \AA \times 65 \pm 10 \AA$. Substructural details, visible on certain particles (arrowed in Pl. I, fig. 2), suggest that they may be composed of three segments. If one assumes the particles to be cylindrical with a partial specific volume, $\overline{\mathrm{V}}=0.6 \mathrm{ml} . / \mathrm{g}$. (see Schramm, Westphal \& Lüderitz, 1952), a particle weight of about I million may be calculated. This figure is in good agreement with an estimate made from sedimentation studies on the complex (Marsh \& Crutchley, 1967).

Extraction of Fraction D2.S I with phenol-water produced linear aggregates of various degrees of polymerization (Pl. 2, fig. 3). Electron micrographs of this extract resemble those of the purified phenol-water extract (P I) from the parent intact bacterial cells (Pl. 2, fig. 4), although substructural details of the chains are not so well defined in this cruder preparation. Published electron micrographs of phenolextracted endotoxin preparations from other serotypes of Escherichia coli, examined after heavy metal shadowing (Schramm et al. 1952; Weidel, Frank \& Martin, 1960) or negative staining (Taylor, Knox \& Work, 1966) show similar chain-like structures.

The aqueous ether extract (E) of the bacteria contained a heterogeneous mixture of rods and chains of various lengths (Pl. 3, fig. 5).

It has been postulated that the mild techniques used to extract and purify free endotoxin (Fraction D2.S I) yield essentially unaltered native endotoxin complexes, whereas chemical extraction of bacteria leads to degradation and aggregation of the native material (Marsh \& Crutchley, 1967). A comparison of the electron micrographs of different preparations of endotoxin (Pls. I-3) show these assumptions to be justified experimentally. Rod-like particles considered to be the native lipopolysaccharideprotein complex of endotoxin appeared to be the same in both crude and highly purified preparations of free endotoxin (Pl. I, fig. I, 2), showing that no apparent structural alteration took place during purification. On the other hand, aggregated material was produced by the removal of protein from the endotoxin complex during phenol-water extraction of purified free endotoxin (Pl. 2, fig. 3) or of bacteria (Pl. 2, fig. 4). 'Conventional aqueous ether endotoxin' (Pl. 3, fig. 5), prepared by a somewhat milder procedure, contains many rods together with some aggregated material. Ribi et al. (1964) showed that this type of preparation still contained a significant amount of protein. It therefore seems most probable that degradation, accompanied by the subsequent tendency towards aggregation, results mainly from the removal of protein from the endotoxin complex.

Schramm et al. (1952) showed that the degree of aggregation of the protein-free phenolic extract was affected significantly by altering the $\mathrm{pH}$ value of the solution: at highly alkaline $\mathrm{pH}$ values particularly marked aggregation occurred, whilst at more nearly neutral $\mathrm{pH}$ values monomeric 'pearls' were observed.

All phenol-extracted endotoxins from Escherichia coli $\mathrm{O}_{7} 8 \mathrm{~K} 80$, prepared according to the method of Marsh \& Crutchley (1967), were found to be aggregated when examined after negative staining at $\mathrm{pH}$ 5.3. At higher values $(\mathrm{pH}$ 9-II) aggregated material was also observed, although the quality of the stained preparations was

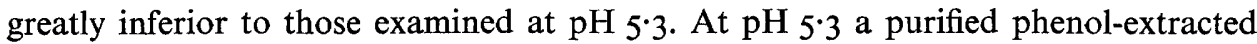
endotoxin from E. coli O I I prepared by Professor Westphal (supplied through the courtesy of Dr C. G. Pope and D. Gall) was found to consist entirely of monomeric 
'pearls' (Pl. 3, fig. 6) similar to those found in a comparable preparation from E. coli O 8 (Schramm et al. 1952). At greater $\mathrm{pH}$ values both of these preparations were aggregated. Differences in the tendency of different preparations of phenol-extracted endotoxin to aggregate may be a feature of their different bacteriological serotypes or of variations in the preparation procedures, leading to products differing in their extent of degradation.

Schramm et al. (1952) concluded that the aggregated material possessed a "pearl chain-like' structure. In certain of the aggregates examined in the present study (arrowed in Pl. 2, fig. 3) there is evidence of 'pearl chains', although the resolution is insufficient to demonstrate such structures unequivocably.

Endotoxin complexes have recently been described as 'rods and hollow spheres of varying sizes' (Knox, Cullen \& Work, 1967); both the rods and the spheres have been described to have 'a bimolecular leaflet-like structure' (Shands, Graham \& Nath, I967; Rothfield \& Horne, 1967). No such 'leaflets' were observed in the present study, probably due to differences in the endotoxin preparations examined. Indeed, it is clear from the recent studies by many workers that endotoxin complexes may present widely different aspects under the electron microscope, depending on their method of preparation. Evidence has been presented here that the endotoxin complex from a virulent strain of Escherichia coli, $\mathrm{O}_{78} \mathrm{~K} 80$, when released into the supernatant culture fluid, consists of a rod-like particle of molecular weight about I million. This entity can be further degraded by physical and chemical treatments to produce the complex structures often observed when cell-wall endotoxin preparations are examined with the electron microscope.

\section{Non-toxic fraction}

All attempts to reveal the non-toxic substance (Fraction DI.S I) by negativestaining proved to be unsuccessful. This finding is in agreement with experiments of Drs Ribi, Anacker, Brown, Haskins, Malmgren, Milner \& Rudbach, reported by Rudbach et al. (1967), who have shown that their non-toxic fraction, NPP, extracted from bacteria, was a long narrow rod-like molecule (I300 $\AA \times$ I6 $\AA$ ).

\section{Cell-wall fragments}

Despite the lack of success in detecting the non-toxic fraction (D I.S I) under the electron microscope, all preparations of this substance were found to contain a very small percentage of larger fragments, heterogeneous in particle size, but exhibiting considerable structural similarity within themselves. These fragments were also detected in the unfractionated culture supernatants and occasionally in the toxic fraction (D2.S I). Photographs of some well-defined fragments are shown in P1. 4, fig. 7, 8, 9, Io. Along their major axes, the fragments show a ridged structure, not generally penetrated by the staining agent. The ridges were occasionally observed to divide into two or more branches (e.g. lower inset, P1. 4, fig. 7). It appears that the ridges constitute the main external supporting structure of the fragments and assist in containing the amorphous internal material, which is more easily penetrated by the stain (Pl. 4, fig. Io). The width of the ridges varies between about I4 and $30 \AA$. Plate 4, fig. 7 (lower inset), illustrates a branching of the 'ridges', the width of which lies between I4 and $17 \AA$. These dimensions suggest that the ridges may, in this case, be composed of a single-branched macromolecule. 
Most probably the fragments are produced by the detachment from the bacteria of 'finger-shaped elements' which emanate from the cell wall of Escherichia coli (Bayer \& Anderson, 1965). These authors also reported that 'sausage-shaped bodies' and 'droplets' were easily detached from the cell walls, particularly by exposing the ghosts to distilled water or $0.9 \% \mathrm{NaCl}$ solution.

The overall dimensions of the particles usually observed in the present work were I 250-1750 $\AA$ long $\times$ I50-230 $\AA$. One complex particle (Pl. 4, fig. 8) was found to be $4 \mathrm{IIO} \AA$ in length, and diameters of about 80 and $300 \AA$ have occasionally been observed. These are similar to those measured by Bayer \& Anderson (up to I $500 \AA$ long $\times$ I00-250 $\AA$ ). In the latter case no structural detail was observed on the fragments. Bayer \& Anderson (1965) considered the fragments to be lipoprotein in nature. Should this be the case, it may partly account for the small percentage of lipid and protein (I-2\% of each) found in the non-toxic fraction D I.S I (Marsh \& Crutchley, I967) in which most of the fragments have been found in the present study.

The authors wish to thank Drs M. Sterne and M. J. Crutchley for useful discussions during this investigation and $\mathrm{Mr} \mathbf{J}$. Short for help in preparing the plates.

\section{REFERENCES}

Anacker, R. L., Finkelstein, R. A., Haskins, W. T., Landy, M., Miner, K. C., Ribi, E. \& Stashak P. W. (1964). Origin and properties of naturally occurring hapten from Escherichia coli. J. Bact. 88, 1705 .

Bayer, M. E. \& Anderson, T. F. (1965). The surface structure of Escherichia coli. Proc. natn. Acad. Sci. U.S.A. 54, 1952.

Crutchley, M. J., Marsh, D. G. \& Cameron, J. (1967). Free endotoxin. Nature, Lond. $214,1052$.

Crutchley, M. J., Marsh, S. G. \& Cameron, J. (1968). Biological studies on free endotoxin and a non-toxic material from culture supernatant fluids of Escherichia coli $\mathrm{O}_{78 \mathrm{~K} 8 \mathrm{o}}$. J. gen. Microbiol. 50, $4 \mathrm{I} 3$.

Knox, K. W., Cullen, J. \& Work, E. (1967). An extracellular lipopolysaccharide-phospholipidprotein complex produced by Escherichia coli grown under lysine-limiting conditions. Biochem. J. ro3, 192.

MARSh, D. G. \& CRUTChley, M. J. (1966). Bacterial lipopolysaccharides. Br. patent application no. $48317 / 66$.

Marsh, D. G. \& Crutchley, M. J. (1967). Purification and physico-chemical analysis of fractions from the culture supernatant of Escherichia coli $078 \mathrm{~K} 80$ : free endotoxin and a non-toxic fraction. J. gen. Microbiol. 47, 405.

Ribi, E., Haskins, W. T., LANDY, M. \& Milner, K. C. (I96I). Preparation and host-reactive properties of endotoxin with low content of nitrogen and lipid. J. exp. Med. I14, 647.

Ribi, E., Anacker, R. L., Fukushi, K., Haskins, W. T., Landy, M. \& Milner, K. C. (i964). In Bacterial Endotoxins. Ed. by M. LANDY and W. BRAUN. p. 16. Institute of Microbiology, Rutgers University Press.

ROTHFIELD, L. \& HoRNe, R. W. (1967). Reassociation of purified lipopolysaccharide and phospholipid of the bacterial cell envelope: electron microscopic and monolayer studies. J. Bact. 93, 1705.

Rudbach, J. A., Anacker, R. L., Haskins, W. T., Milner, K. C. \& Ribi, E. (I967). Physical structure of a native protoplasmic polysaccharide from Escherichia coli. J. Immunol. $98, \mathrm{I}$.

Schramm, G. von, WestPhal, O. \& Lüderitz, O. (I952). Über bakterielle Reizstoffe. III. Mitt.: Physikalisch-chemisches Verhalten eines hochgereinigten Coli-Pyrogens. Z. Naturf. $7 b, 594$.

Shands, J. W., Graham, J. A. \& NATH, K. (1967). The morphologic structure of isolated bacterial lipopolysaccharide. J. molec. Biol. $25,15$.

9

G. Microb. 52 
TAYLOR, A., KNOX, K. W. \& WoRK, E. (I966). Chemical and biological properties of an extracellular lipopolysaccharide from Escherichia coli grown under lysine-limiting conditions. Biochem. J. 99, 53.

Weidel, W., Frank, H. \& Martin, H. H. (1960). The rigid layer of the cell wall of Escherichia coli strain B. J. gen. Microbiol. 22, 158.

WestPHAL, O., LüderITZ, O., EichenBerger, E. \& KeIDERLing, W. (I952). Über bakterielle Reizstoffe. I. Mitt. Reindarstellung eines Polysaccharid-Pyrogens aus Bacterium coli. Z. Naturf. 78, 536.

\section{EXPLANATION OF PLATES}

Preparations from cultures of Escherichia coli $\mathrm{O}_{78} \mathrm{~K} 80$

All preparations were negatively stained with phosphotungstate at $\mathrm{pH} 5 \cdot 3$. Horizontal lines shown in the bottom left-hand corners of photographs represent $1000 \AA$, except that in Pl. 4, fig. Io, which represents $250 \AA$.

\section{Plate I}

Fig. I. Fraction precipitated from the culture supernatant fluid by saturated ammonium sulphate. $\times 213,000$.

Fig. 2. Toxic fraction D 2.S I, purified from the crude fraction shown in fig. I by chromatography on DEAE-cellulose and Sephadex columns. Substructure of rods indicated by arrow. $\times 213,000$.

\section{Plate 2}

Fig. 3. Toxic fraction $\mathrm{D}_{2}$. $\mathrm{S}_{\mathrm{I}}$ after treatment with phenol water at $65^{\circ}$. Possible pearl chain-like structure indicated by arrow. $\times 213,000$.

Fig. 4. Toxic fraction P I, obtained by purifying a crude phenol water extract of bacteria on Sephadex G 100. $\times 213,000$.

\section{Plate 3}

Fig. 5. Toxic fraction E: conventional aqueous ether extract of bacteria. $\times 213,000$.

Fig. 6. Westphal's toxic fraction purified from a phenol water extract of bacteria. $\times 213,000$.

\section{Plate 4}

Figs. 7, 8. Fragments considered to be derived from cell wall. $\times 213,000$.

Fig. 9. Fragment from cell walls observed in a crude ammonium sulphate precipitate of the culture supernatant of E. coli $\mathrm{O} 78 \mathrm{~K} 80 . \times 213,000$.

Fig. I0. Fragment shown in Fig. 9. $\times 710,000$. 
Journal of General Microbiology, Vol. 52, No. I

Plate I

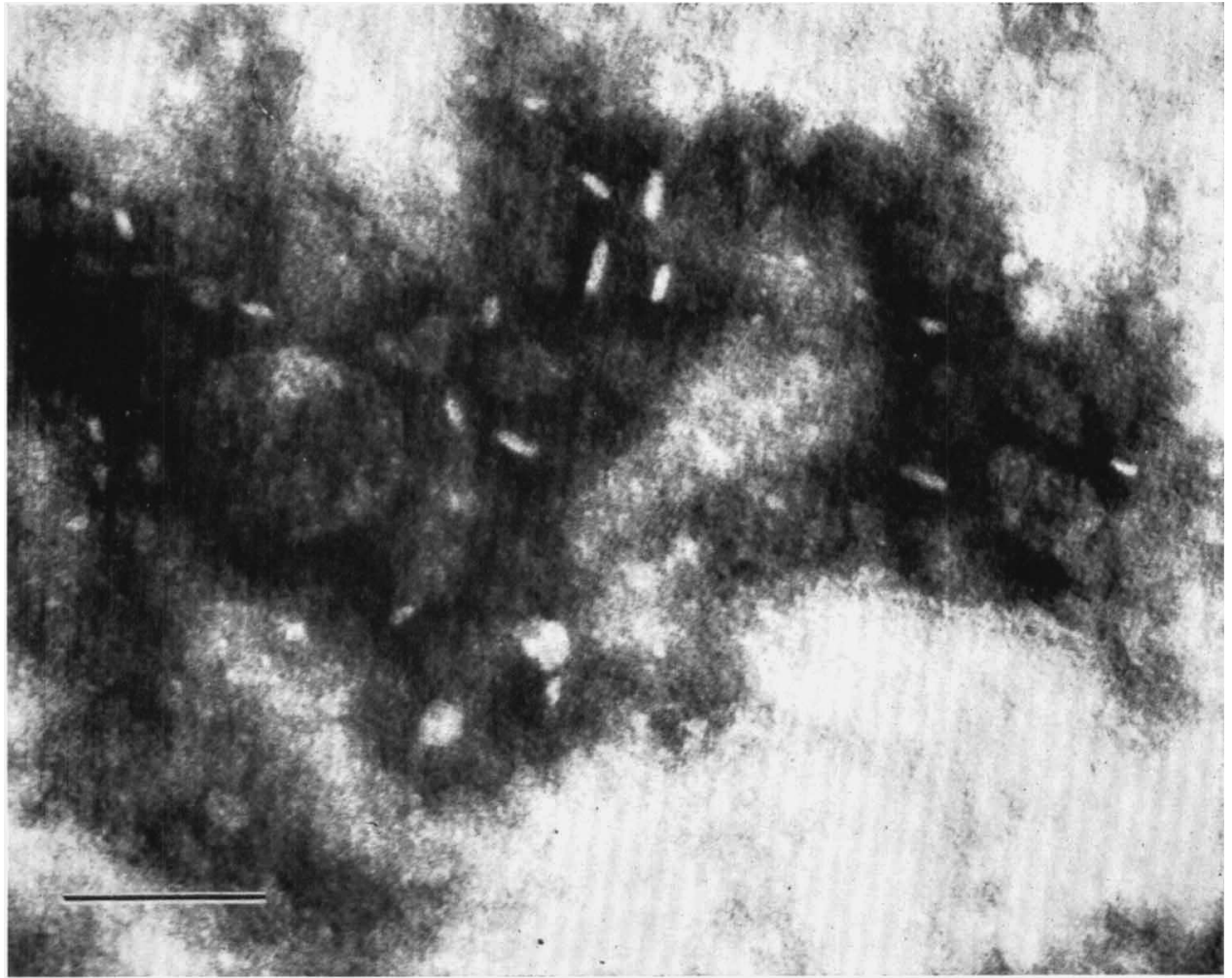

Fig. I

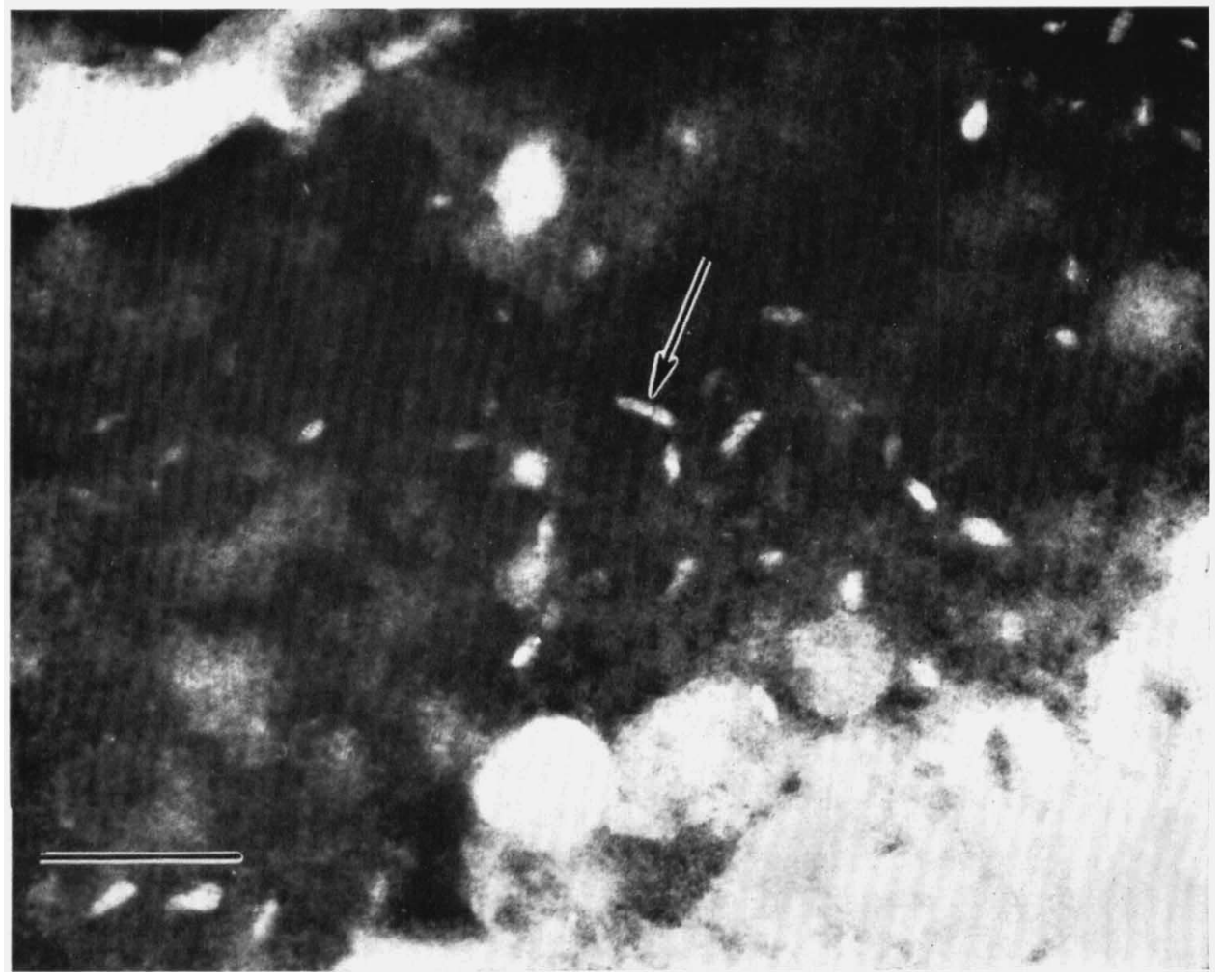

Fig. 2

D. G. MARSH AND P. D. WALKER 
Journal of General Microbiology, Vol. 52, No. I

Plate 2

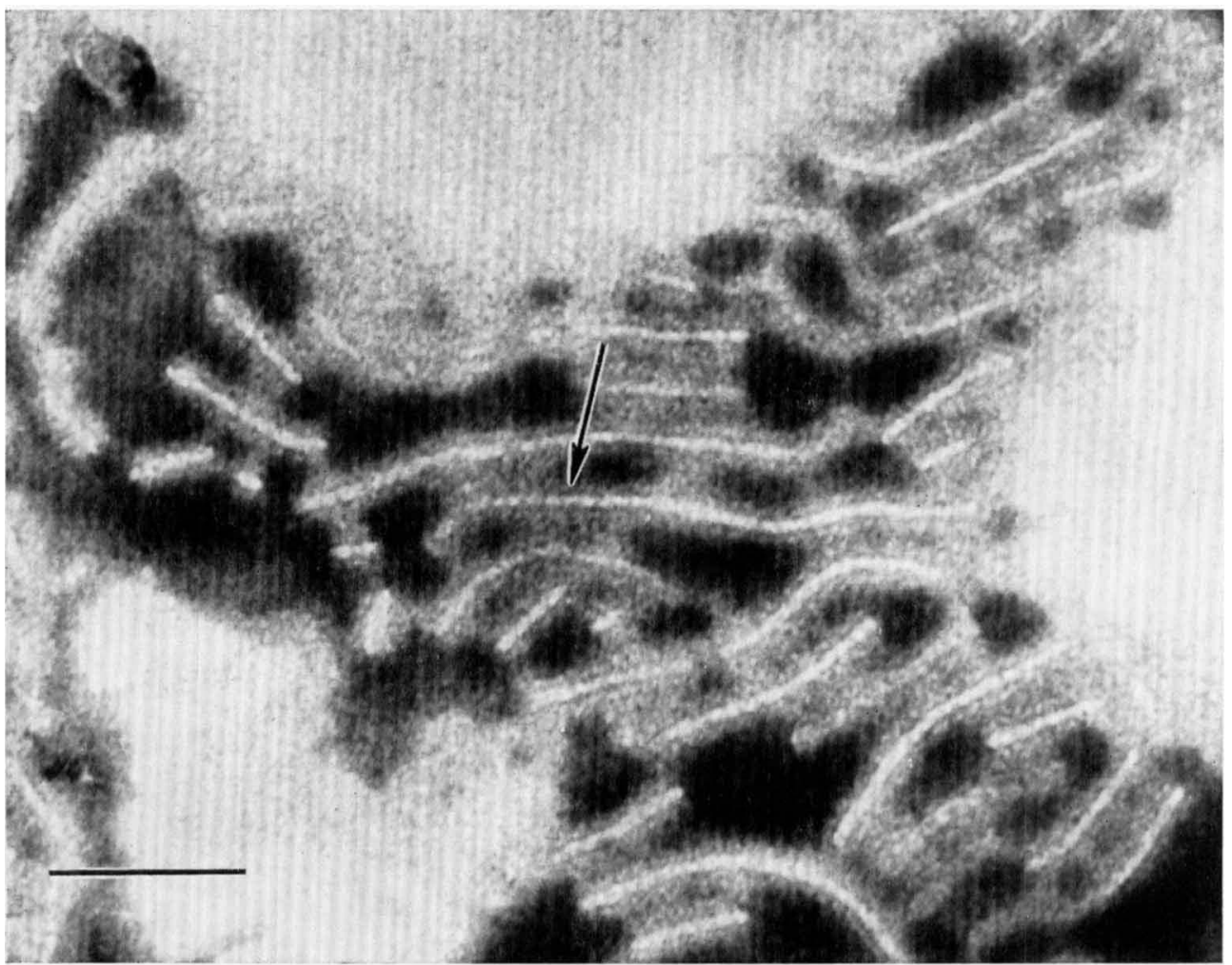

Fig. 3

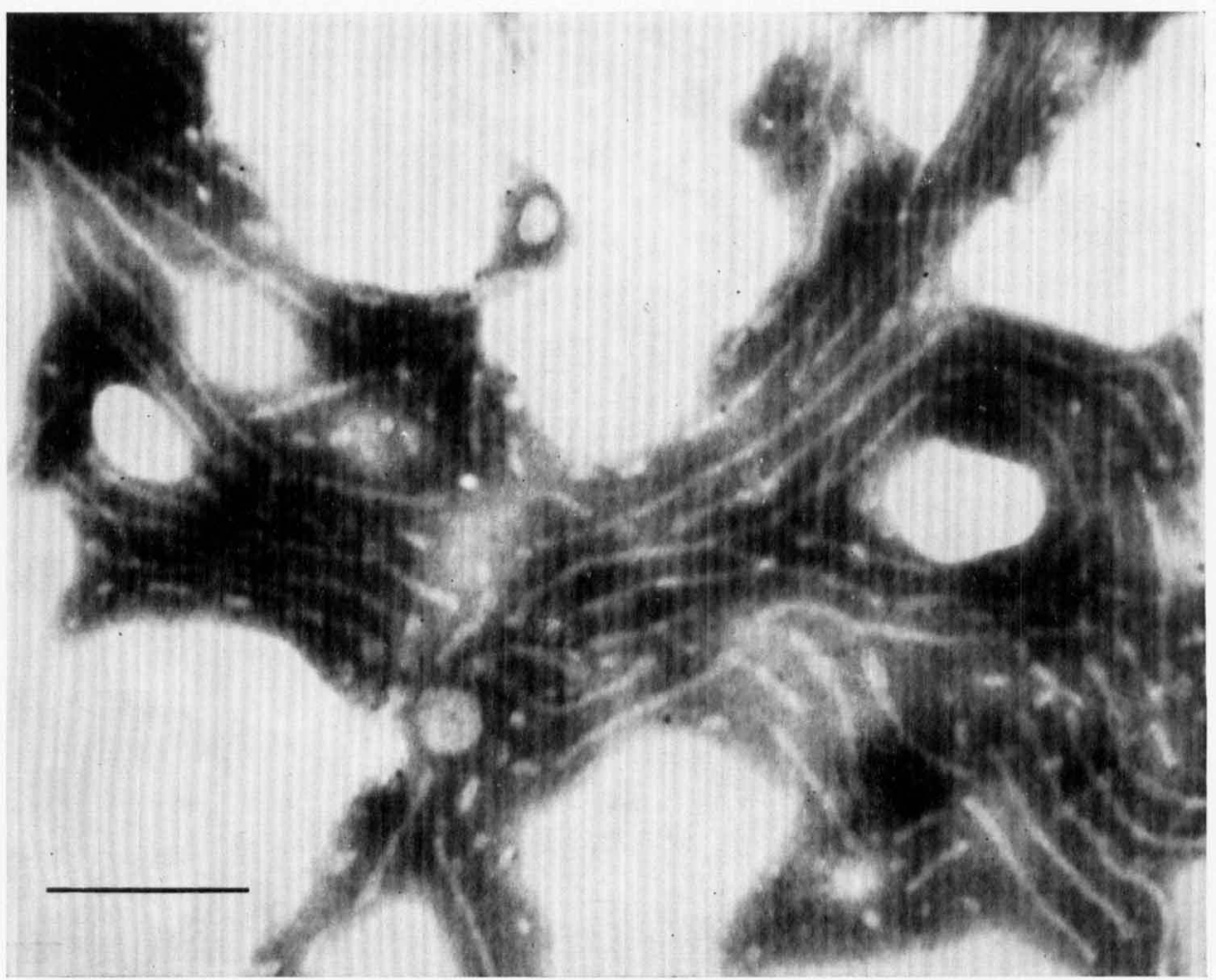

Fig. 4

D. G. MARSH AND P. D. WALKER 
Journal of General Microbiology, Vol. 52, No. I

Plate 3

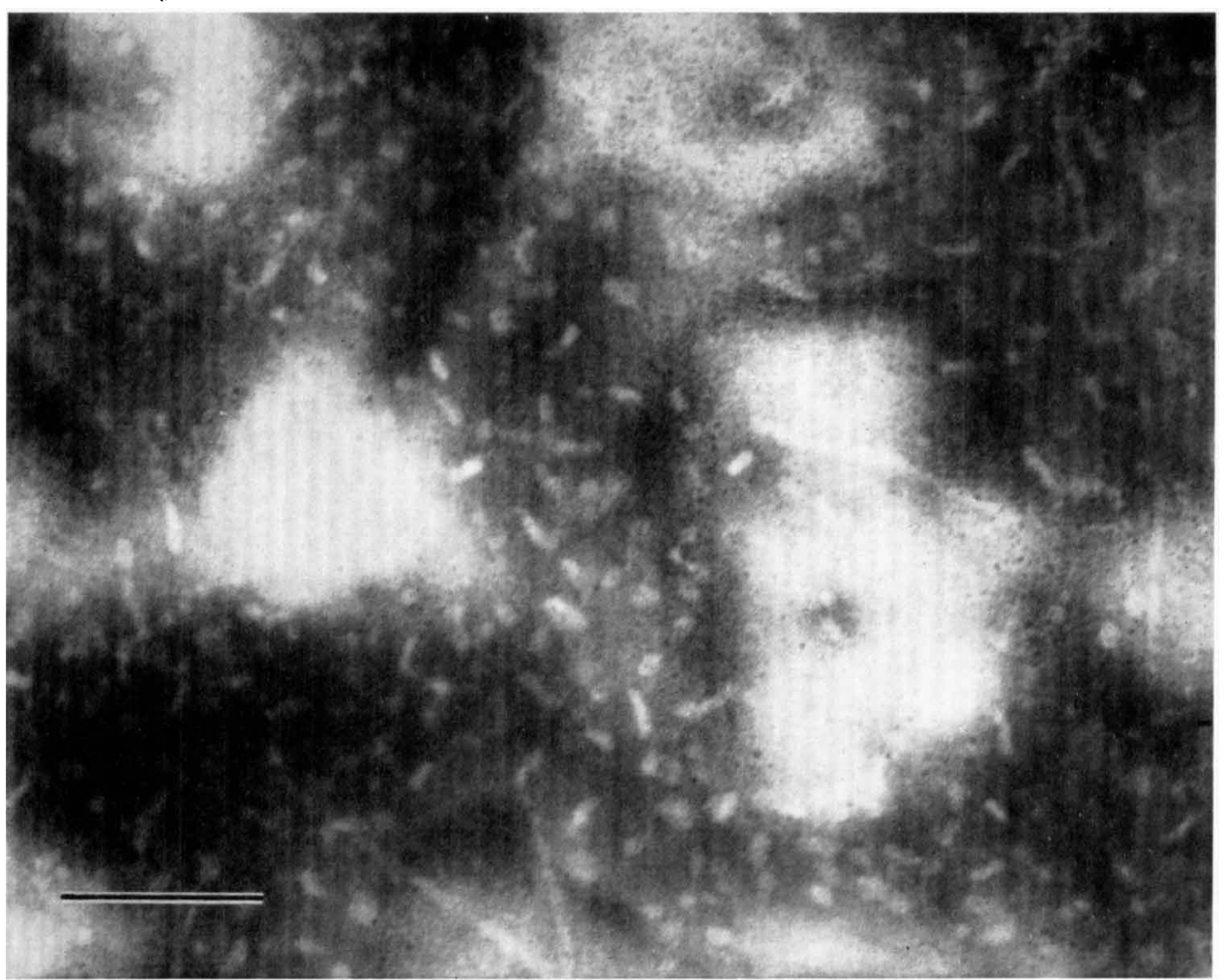

Fig. 5

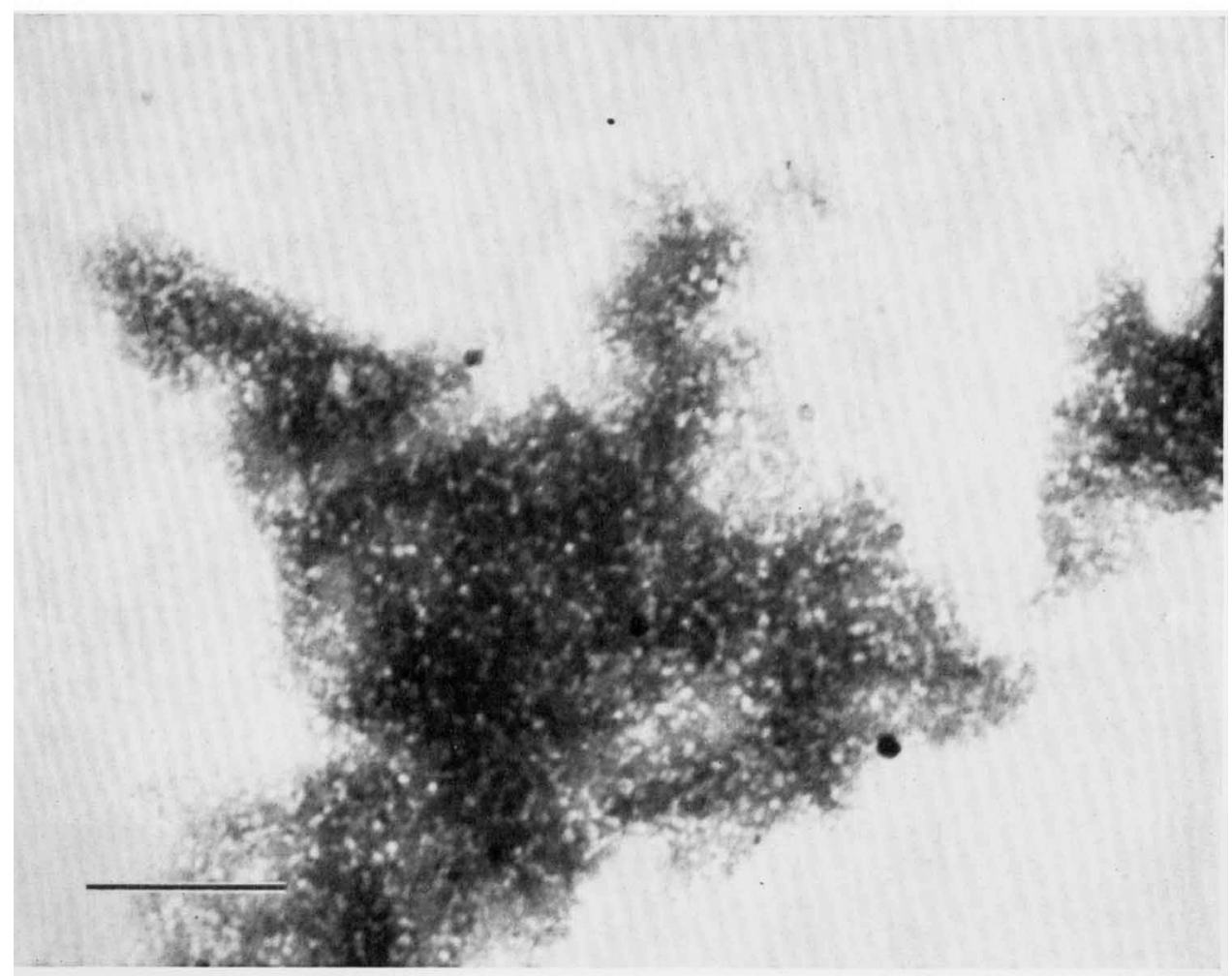

Fig. 6

D. G. MARSH AND P. D. WALKER 
Journal of General Microbiology, Vol. 52, No. I

Plate 4

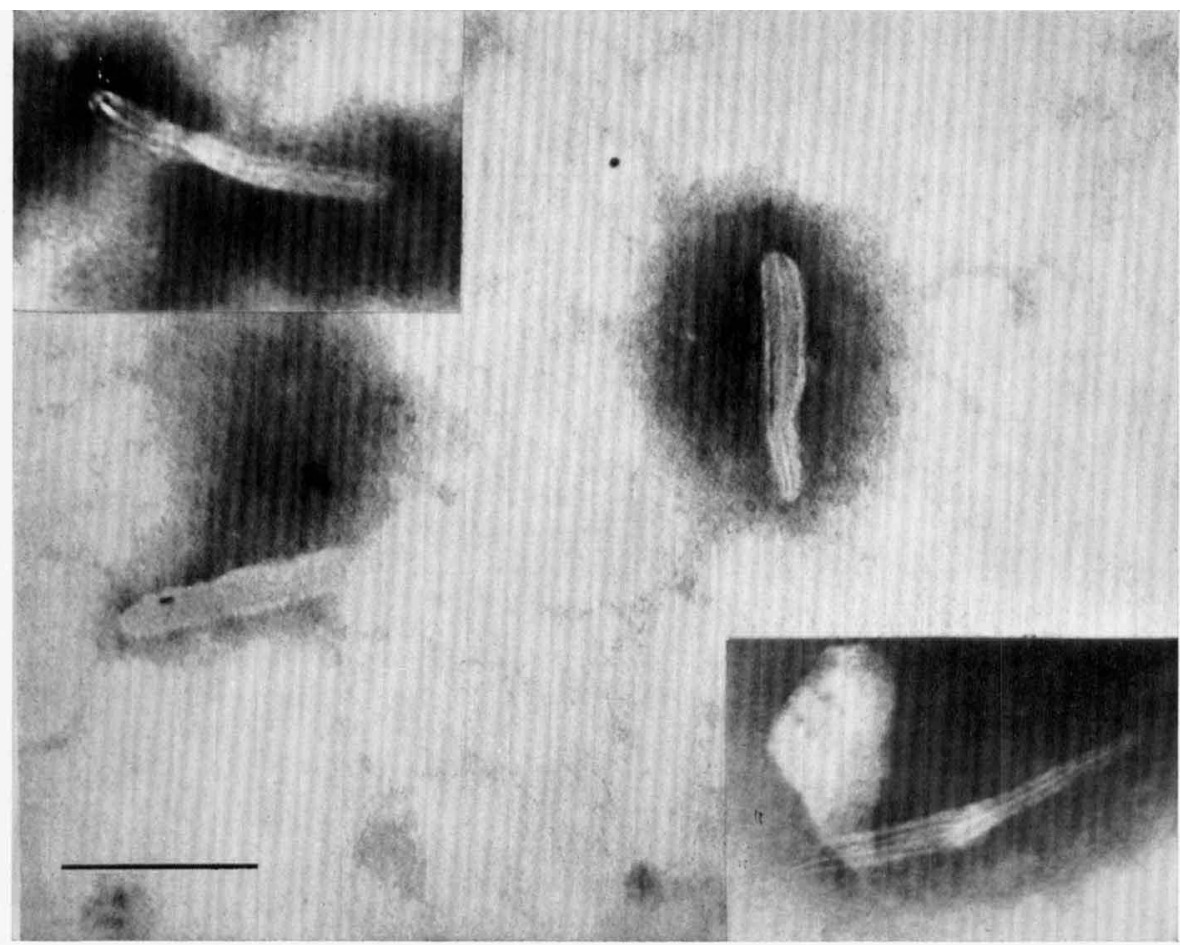

Fig. 7

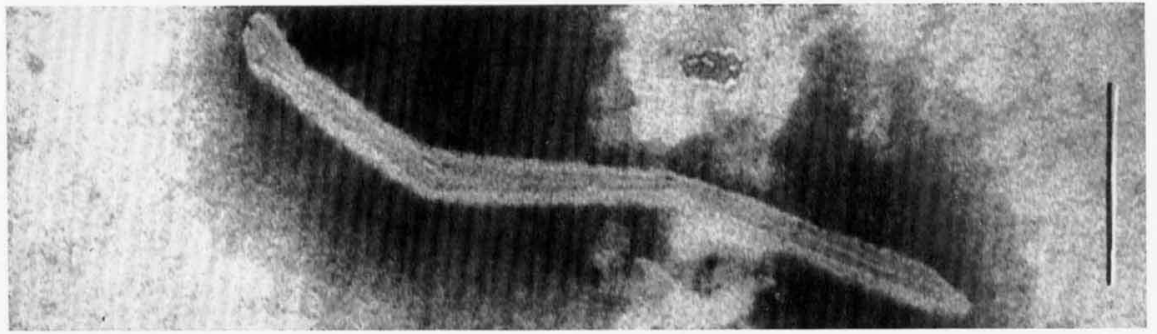

Fig. 8

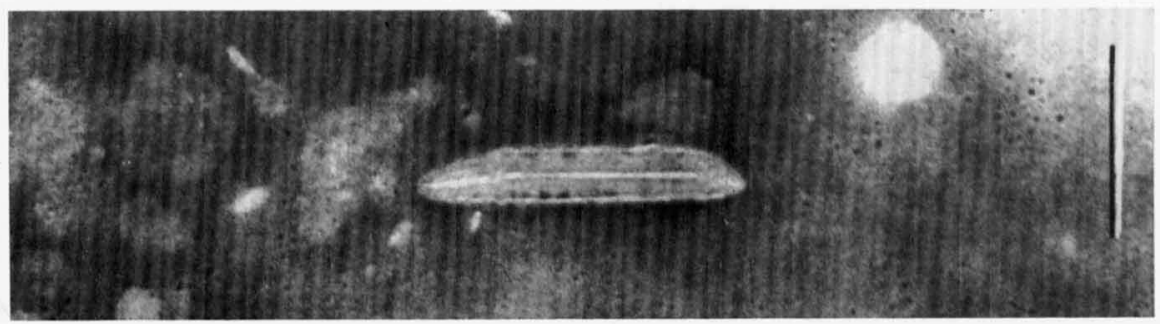

Fig. 9

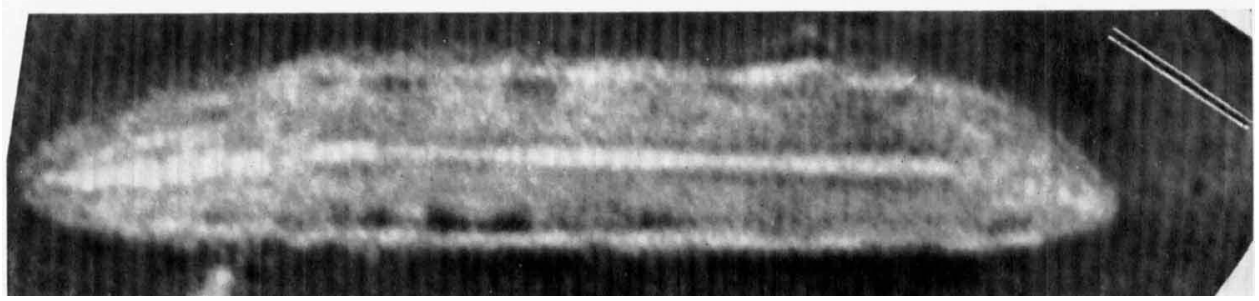

Fig. 10

D. G. MARSH AND P. D. WALKER 